\title{
Spatial Analysis and Visualization of Geographic Access to Food in the Capital Area of Bulungan Regency, North Kalimantan Province
}

\author{
Bowo Susilo ${ }^{1, *}$, Rika Harini ${ }^{2}$ \\ ${ }^{1}$ Department of Geographic Information Science, Faculty of Geography, Universitas Gadjah Mada, \\ Yogyakarta \\ ${ }^{2}$ Department of Environmental Geography, Faculty of Geography, Universitas Gadjah Mada, \\ Yogyakarta \\ *) Corresponding author (e-mail: bowosusilo@ugm.ac.id)
}

Received: 5 November 2018 / Accepted: 25 November 2018 / Published: 25 November 2018

\begin{abstract}
Recently, food security becomes a priority for many governments particularly in developing countries. Food security has four dimensions, i.e. availability, accessibility, stability, and utilization. This study examined food accessibility in term of geographic access, i.e. the contribution of the geographic environment to food choices and consumption. The study located in Tanjung Selor Subdistrict, the capital region of Bulungan Regency as well as North Kalimantan Province. Geographic access to food was analysed based on spatial distribution of food stores, settlement, and availability of transportation network. Spatial analysis, i.e. coverage, density, and network analysis, as well as the spatial visualisation were performed using tools available in GIS software. This study revealed some circumstance related to geographical access to food in the study area. Geographical access to food for non-motorized people is limited. Nonmotorized people have to walk more than $1 \mathrm{~km}$ to the nearest food store. Access to food for motorised people is somewhat different. Their geographical access, in general, were categorised as easy to moderate. This situation indicates that the availability of public transport or vehicle ownership is necessary to improve access to food.
\end{abstract}

Keywords: Food Security, Geographic Access, Spatial Analysis, Visualization

\begin{abstract}
Abstrak. Ketahanan pangan saat ini menjadi prioritas sejumlah pemerintah terutama di negara berkembang. Ketahanan pangan memiliki empat dimensi atau aspek yaitu ketersediaan, aksesibilitas, stabilitas dan pemanfaatan. Penelitian ini mengkaji aksesibilitas terhadap pangan, dalam konteks aksesibilitas geografis. Penelitian berlokasi di Kecamatan Tanjung Selor yang merupakan wilayah ibukota Kabupaten Bulungan dan sekaligus wilayah ibukota Provinsi Kalimantan Utara. Aksesibilitas geografis dianalisis berdasarkan distribusi keruangan dari tempat penjualan bahan pangan dan lokasi permukiman serta ketersediaan jaringan transportasi. Analisis keruangan yang meliputi cakupan, kepadatan dan analisis jaringan dilakukan dengan bantuan perangkat lunak SIG. Hasil penelitian menunjukkan beberapa hal terkait dengan akses geografis terhadap pangan di daerah penelitian. Penduduk yang tidak memiliki kendaraan bermotor mempunyai akses yang terbatas. Mereka harus menempuh jarak lebih dari $1 \mathrm{~km}$ ke pasar atau toko penjual bahan pangan yang terdekat. Penduduk yang memiliki kendaraan bermotor, secara umum mempunyai akses yang mudah hingga sedang. Kondisi ini menunjukkan bahwa ketersediaan transportasi umum atau kepemilikan kendaraan bermotor sangat diperlukan untuk meningkatkan akses geografis terhadap pangan bagi penduduk di daerah penelitian.
\end{abstract}

Kata kunci: Analisis Spasial, Visualisasi, Akses Geografis, Ketahanan Pangan

\section{Introduction}

Recently, food security becomes a priority for many governments particularly in developing countries. Therefore, many studies related to food security have been conducted by many researchers (e.g. 
Widiyanto, 2018; Harini et al., 2018; Cen, 2017; Le et al., 2015). Food security has been defined as people having "access to sufficient, safe, and nutritious food which meets their dietary needs and food preferences for an active and healthy life" (FAO, 2013). In addition to this definition, FAO stated that food security has four dimensions, i.e. availability, accessibility, stability, and utilisation. All dimension are equally essential. However, access is considered more interesting for some reason. Access to food has relations to a broad aspect of livelihood hence researchers examined access from different perspectives.

Physical and non-physical factors influence access to food. Geographical environment or landscape situation, availability of food store, and the availability of transportation infrastructure are some examples of physical factors related to food accessibility. Individual or household income, culture, and knowledge are some examples of non-physical factors. Some researchers focused on physical factors (e.g. Le et al., 2015) and the others have focused on non-physical factors (e.g. Leroy et al., 2015) or both (e.g. Krizan et al., 2015; Yeager and Gatrell, 2014; Choi and Suzuki, 2013; Eckert and Shetty, 2011). This study focused on physical factors, i.e. geographic environment related to food access, therefore, termed as geographic access.

Spatial analysis plays an important role as a methodological basis in conducting geographical research. Fotheringham and Rogerson (2009) defined spatial analysis as a general term to describe a technique that uses the locational information in order to understand better the processes generating the observed phenomena. In the study of food security, it has been utilised to examine the accessibility aspect, particularly geographical accessibility. Susilo (2016) used spatial analysis and spatial statistic to access spatial variability of agricultural land conversion. Le et al. (2015) employed three types of spatial analysis, i.e. coverage, density, and proximity, to evaluate geographical access to food in
Dorset Municipality, Tasmania, Australia. Cen (2017) compared gravity-based and unitbased approach in food access research in Franklyn County, Ohio, USA. These previous studies implicitly indicate that assessment of geographical access to food is indispensable especially for a particular region with particular consideration.

Tanjungselor is a subdistrict within Bulungan Regency North Kalimantan Province. North Kalimantan is the youngest province in Indonesia located in the northern part of Kalimantan (Borneo) Island immediately adjacent to Malaysia. Tanjung Selor is interesting place in relation to study of food security particularly the accessibility aspects. From a socio-political perspective, it is a central place because of its position as a capital region of a regency and a province. From the geographical landscape point of view, this region is specific since its situated in a delta area known as Delta Kayan. While land transportation infrastructure is being actively undertaken, water transportation is still the primary modes of transportation in this area. In addition, water transportation is currently the main alternative for connecting this place to another centre of economic activities in North Kalimantan, i.e. Tarakan Island. Since the geographical landscape of this area is a considerable impediment, a study of geographical access is quite relevant. In relation to the study of food security, identifying areas where food access is geographically limited could help local government to formulate appropriate policy. The main objective of this study is to examine food accessibility, in term of geographic access, of the people who live in the capital area of Bulungan Regency. In addition, this study attempt to demonstrate the utilization of GIS in conducting a spatially explicit analysis for accessibility assessment. Assessment of geographic access through a spatially explicit analysis and visualisation may provide valuable information for the local government. 


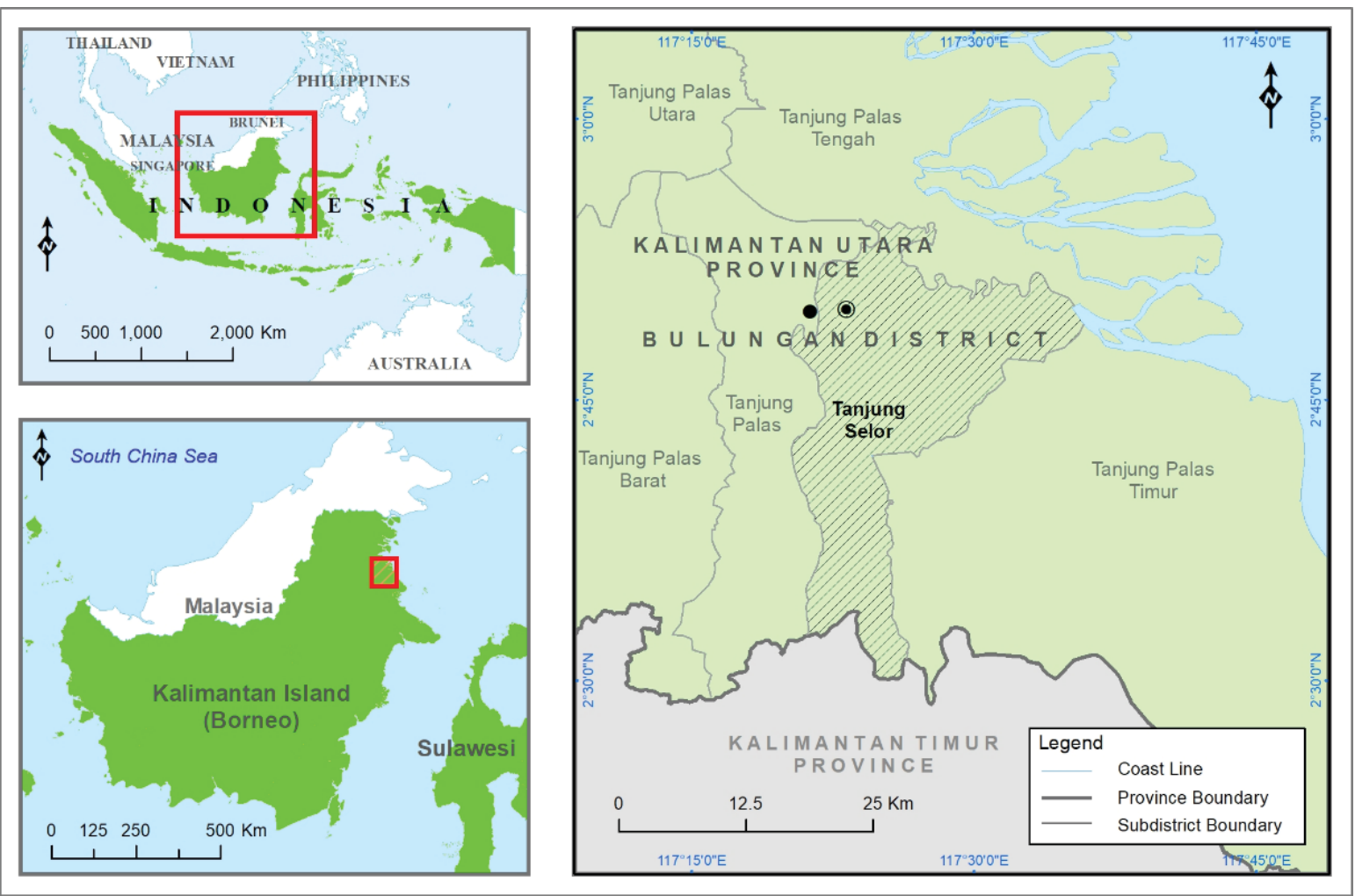

Figure 1. Study area: Tanjung Selor Subdistrict, Bulungan Regency, North Kalimantan Province.

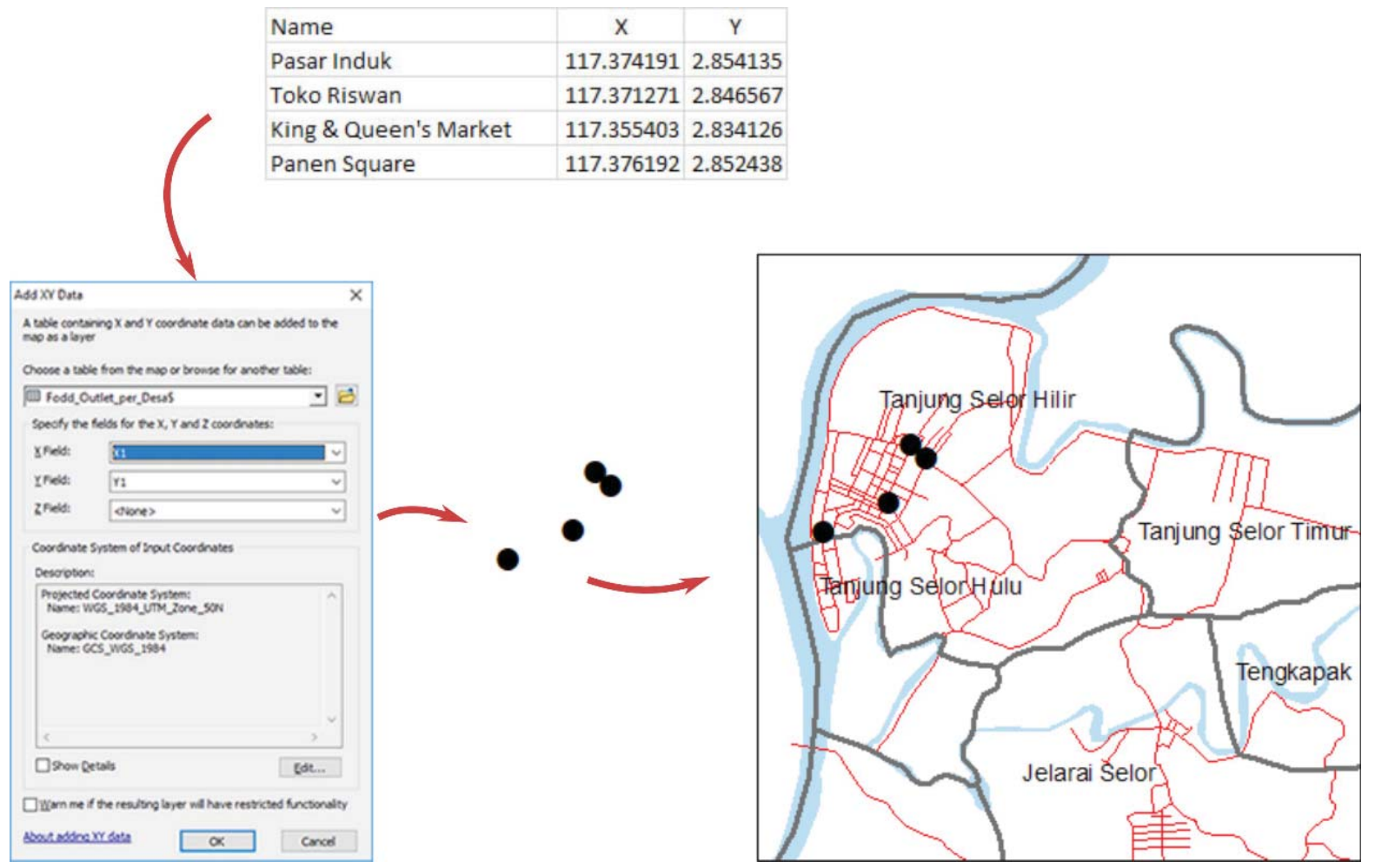

Figure 2. Illustration of coordinate plotting for mapping the spatial distribution of food stores.

\section{Research Method}

Analysis of geographic access to food in this study was conceptually based on the spatial interaction between food supply and demand. Availability of food stores in a certain area serves as food supplies while the population in that area and its surrounding neighbourhood serve as food demands. Spatial 
separation, in term of distance along road networks, between supply and demand is used as a measure of geographic access to food. This method is a particular form of spatial analysis which commonly known as network analysis.

\subsection{Study Area}

The study was conducted in Tanjung Selor Subdistrict, Bulungan Regency, North Kalimantan Province. Tanjung Selor Subdistrict is considered as a central place since the capital of Bulungan Regency as well as the capital of North Kalimantan Province are there. Tanjung Selor Subdistrict consists of nine villages namely Apung, Bumi Rahayu, Gunung Sari, Gunung Seriang, Jelarai Selor, Tanjung Selor Hilir, Tanjung Selor Hulu, Tanjung Selor Timur, and Tengkapak. The study area is shown in Figure 1.

\subsection{Data}

Data used in this study were gathered from various different sources. Data related to food stores were mainly acquired from google map and open street map, some of them were obtained from fieldwork. These data include name, type, and location of food stores. Indonesian topographic maps (RBI) at 1: 50.000 which are available in digital format, were used as sources to obtained data of roads network, administrative boundary and hydrographic features, i.e. main rivers. Partially updating of road networks were performed when possible to ensure the completeness of the data. Demographic data, particularly the number of population, was gathered from a secondary source which is a book namely Kecamatan Tanjung Selor in Figures. This book was published by Central Bureau of Statistics (Badan Pusat Statistik) of Bulungan Regency.

\subsection{Mapping the Spatial Distribution of Food Stores and Population}

Spatial distribution of food stores in the research area was mapped based on data collected from what so-called "crowdsourced" maps. The term "crowdsourced" in the field of geospatial data acquisition refer to data which provided or contributed by a variety of users (Jestico et al., 2016; Johnson et al., 2017). Crowdsourced maps or crowdsourced geographic data (CGD) is also commonly referred to as VGI which stand for volunteered geographic information (Goodchild, 2007; Johnson et al., 2017). Open street map and google map are examples of CGD. Using a combination of open street map and google map, food stores in the research area were identified, and its coordinate locations were obtained. Further, these coordinates i.e. latitude and longitude of each food store were used as a basis for plotting them on a base map. Figure 2 illustrates how coordinate of food stores were plotted in order to map its spatial distribution.

Spatial distribution of the population was simply mapped using a centroid of settlement areas. Settlement areas were identified and delineated based on satellite imagery which is available on google maps. The administrative boundary was overlaid on top of settlement polygon then spatial mean centre analysis was performed to create population centroid for each village. A spatial mean centre is a particular form of spatial cluster analysis which is commonly used to identify the centre of features distributed in a certain area. Figure 3 illustrates how the spatial distribution of the population was mapped using a centroid of the settlement area.

\subsection{Spatial Analysis of the Geographic Access to Food}

Network analysis was performed to measure the distance between the population's centroid and food stores. The distance was measured along road networks. This analysis generates a matrix called origin-destination (OD) cost matrix. Population's centroid serves as origin while the location of the food store serves as the destination. In addition to the OD cost matrix, the analysis could generate the shortest routes connecting population centroid and food stores as illustrated in Figure 4. Green point in Figure 4 represent origin, i.e. population centroid, red points represent destinations, i.e. food stores, grey line represents road networks, and the thick blue line represents shortest routes connecting origin and destinations. 


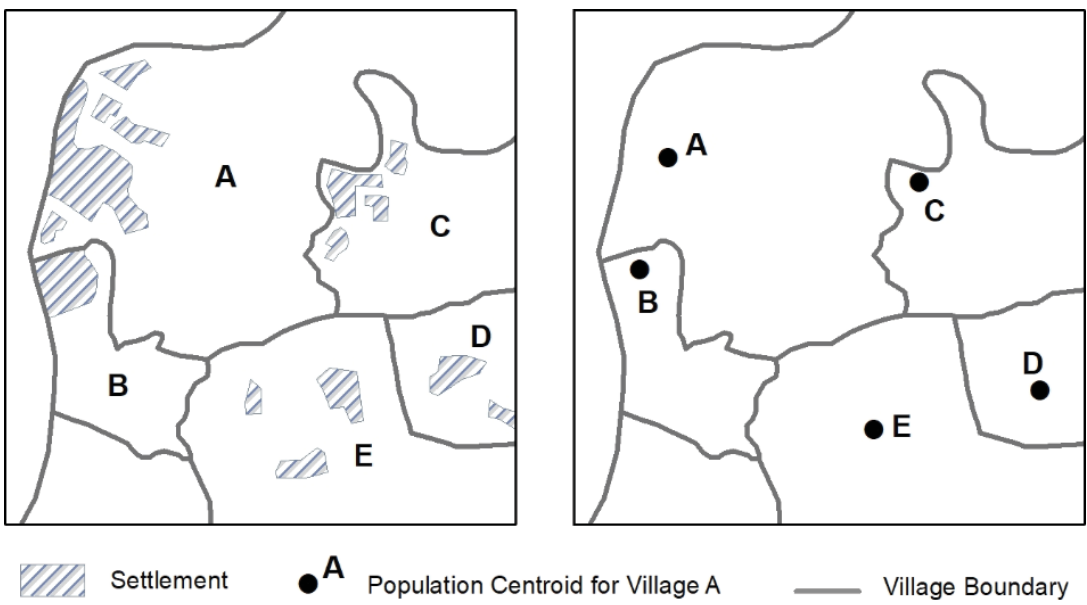

Figure 3. Illustration of Settlement's centroid as a proxy for mapping population centre.

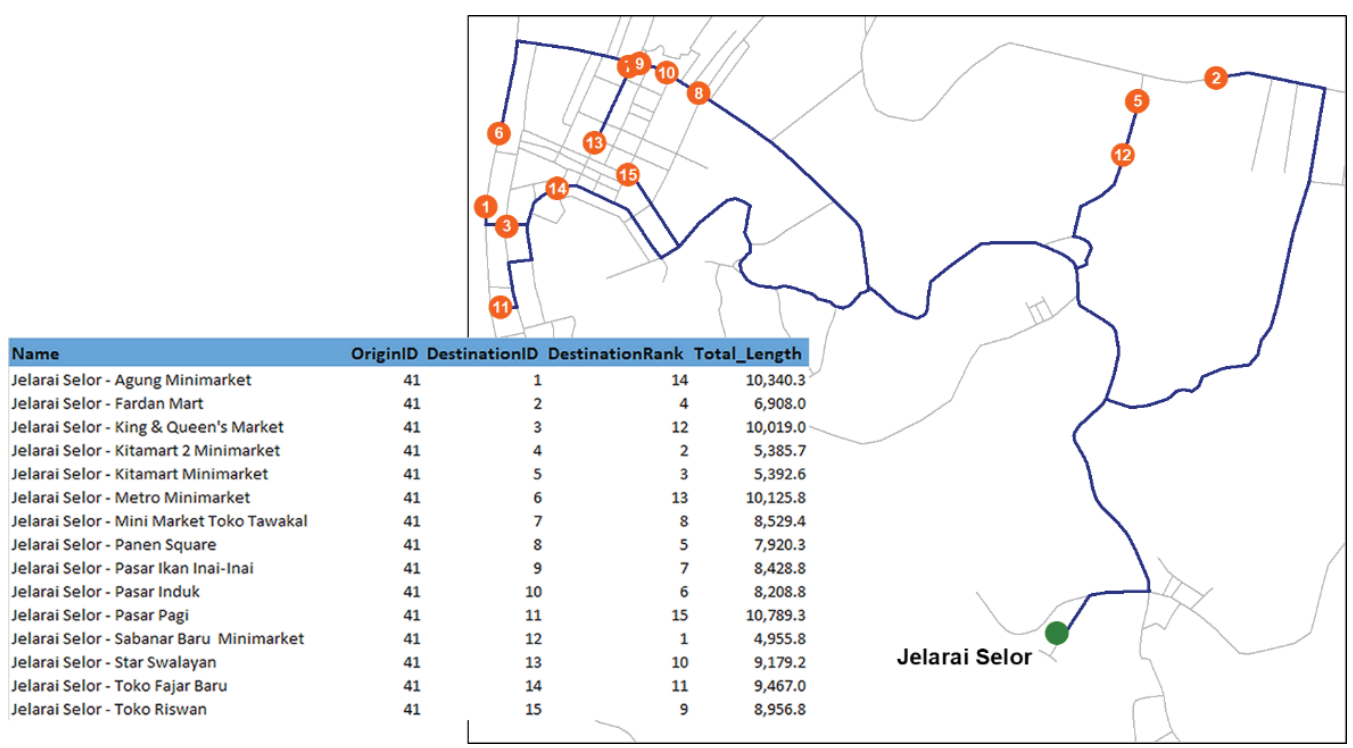

Figure 4. Illustration of network analysis and table derived from $O D$ cost matrix.

Table 1. Classification of geographic access to food.

\begin{tabular}{ccc}
\hline \multirow{2}{*}{ Category of Access } & \multicolumn{2}{c}{ Distance Along Roads to Food store } \\
\cline { 2 - 3 } & Non-Motorized Population & Motorized Population \\
\hline Easy Access & $<400 \mathrm{~m}$ & $<8 \mathrm{~km}$ \\
Moderate Access & $400-1000 \mathrm{~m}$ & $8-16 \mathrm{~km}$ \\
Limited Access & $>1000 \mathrm{~m}$ & $>16 \mathrm{~km}$ \\
\hline
\end{tabular}

2.5. Visualizing Geographic Access to Food Geographic access to food in the study area was visualised based on the result of network analysis. As previously explained, network analysis provides information about the distance between the centre of population and food stores. Since there were 15 food stores involved in network analysis, there were 15 values of distance obtained for each village. Further, a calculation was performed to obtain an average and first quartile value of the distance to food stores for each village. 
Table 2. List of food stores in Tanjung Selor Subdistrict.

\begin{tabular}{lllll}
\hline \multirow{2}{*}{ Name of Food Store } & \multicolumn{1}{c}{ Category } & \multicolumn{2}{c}{ Geographic Coordinate } & Administrative Lo- \\
\cline { 3 - 4 } cation
\end{tabular}
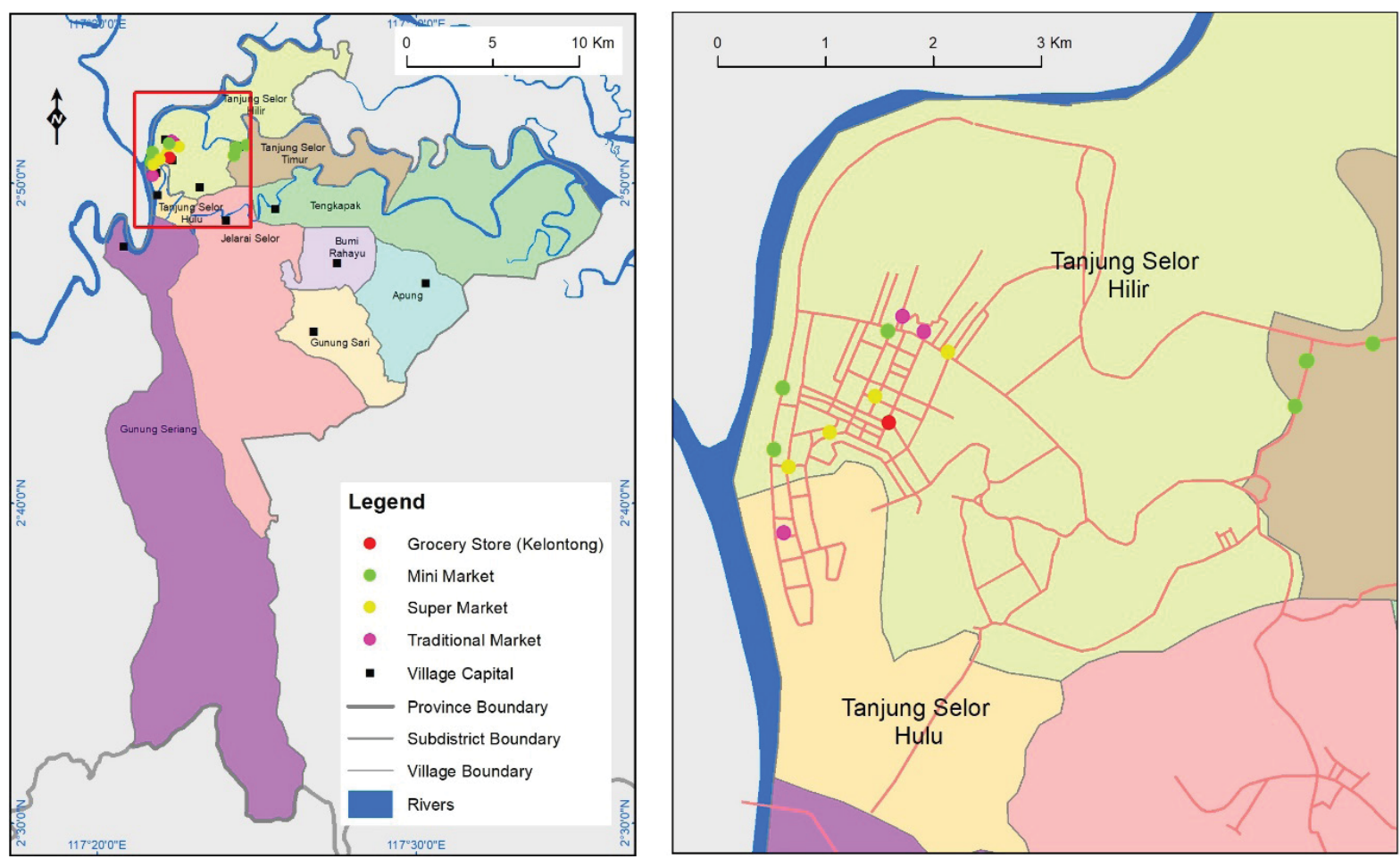

Figure 5. Spatial distribution of food stores in Tanjung Selor Subdistrict.

Average distance to food stores for a village was calculated by summing up the length of all routes then divide the summed values by the number of routes, as shown in Equation 1. In this equation, $x$ is average distance from population centroid of the village $a$ to food store, $x_{\mathrm{i}}$ is the length of a route connecting population centroid of the village a to $i^{\text {th }}$ the food store, and $n$ is the number of routes. Note that the number of routes is equal to the number of food stores, e.g. 15 routes in this example. 


$$
x_{a}=-\frac{1}{n} \sum_{i=1}^{n} x_{a \mathrm{i}}
$$

Equation 2 was used to obtain 1st quartile distance to food store for a village. Distance from a population centroid to all food stores was short ascendingly, i.e. from shortest to longest. Applying Equation 2 will retrieve a value that represents a $25 \%$ shortest distance to food store. Note that $Q$ is quartile, $i$ is a number that represents quartile's order ( $1=$ first, $2=$ second, $3=$ third), and $n$ denote the number of data or values.

$$
\mathrm{Q} i=\frac{i(n+1)}{4}
$$

Based on average and first quartile distance, geographic access to food was classified into three categories (see Table 1). Basically, this classification refers to research conducted by Le et al. (2015). Le et al. (2015) use a distance of $400 \mathrm{~m}$ and $1 \mathrm{~km}$ to classify accessibility for non-motorized people. Nonmotorized people said to have easy access if they lived within $400 \mathrm{~m}$ and limited access if they lived more than $1 \mathrm{~km}$ along the road. For motorized people, a distance of $16 \mathrm{~km}$ is used as a threshold. They were considered to have limited access if they lived outside the $16 \mathrm{~km}$ radius of the nearest food store. This classification was useful for visualisation purpose. Administrative boundary, i.e. village was used as a visualisation unit. In addition, we differentiated geographic access for motorized population and non-motorized population.

\section{Results and Discussion}

\subsection{Availability and Spatial Distribution of Food stores}

There are 15 food stores in the study area, consisting of 4 traditional markets, 3 supermarkets, one grocery store, and seven mini markets. Detail information about these food stores is shown in Table 2. Among these food stores, Pasar Induk is the main food store in Tanjung Selor Subdistrict as well as in Bulungan Regency. As the name suggests, i.e. Induk which mean parent or big, Pasar Induk is the biggest traditional market in the study area and play an important role in distributing food staples for people in that area. It provides a variety of products other than staples. Pasar Induk is administratively located at Tanjung Selor Hilir Village. In addition to Pasar Induk, Tanjung Selor Hilir Village also has many food stores. As shown in Figure 5, all food stores in Tanjung Selor Sub District is mostly located in Tanjung Selor Hilir Village.

Availability of food store in the study area could also be explained using a different measure, i.e. density. Tanjung Selor Sub District is home of 51,996 people with Tanjung Selor Hilir representing the most populous village (Tanjung Selor in Figures 2017). More than $51 \%$ of the population in study area live within Tanjung Selor Hilir. The density of food stores in Tanjung Selor Sub District were calculated using the number of population. The number of food stores is 15 while the total population is 51,996 . Thus the density of food stores in the study area is 0.29 food stores per 1000 people (i.e. 15 food for a total population of 51,996). Previous researchers (Le et al., 2015) used one food store per 1000 people as a threshold for adequate access to food. In the Dorset Municipality, a remote area in Australia where Le et al. (2015) conducted similar research, the density of healthy food stores was 1.3. The density varies in each town with a minimum value of 0.9 and a maximum value of 1.8. Compare to a threshold value as well as the study in the remote area of Australia, food density in Tanjung Selor Sub District is much lower. This indicate that the accessibility of food in the study area is considered limited. The density of the food store is varied within each village. The values range from 0 to 0.9 and Tanjung Selor Timur Village has the highest value. 
Table 3. Origin-destination matrix showing distance between population centroids to food stores.

\begin{tabular}{|c|c|c|c|c|c|c|c|c|c|c|c|c|c|c|c|}
\hline \multirow{2}{*}{ Origin } & \multicolumn{15}{|c|}{ Distance to Destination (Food Store ${ }^{*}$ ) in $\mathrm{Km}$ : } \\
\hline & 1 & 2 & 3 & 4 & 5 & 6 & 7 & 8 & 9 & 10 & 11 & 12 & 13 & 14 & 15 \\
\hline Apung & 25.0 & 21.5 & 24.6 & 20.0 & 20.0 & 24.8 & 23.2 & 22.5 & 23.1 & 22.8 & 25.4 & 19.6 & 23.8 & 24.1 & 23.6 \\
\hline Bumi Rahayu & 18.8 & 15.4 & 18.5 & 13.9 & 13.9 & 18.6 & 17.0 & 16.4 & 16.9 & 16.7 & 19.3 & 13.5 & 17.7 & 18.0 & 17.5 \\
\hline Gunung Sari & 17.4 & 13.9 & 17.0 & 12.4 & 12.4 & 17.1 & 15.5 & 14.9 & 15.4 & 15.2 & 17.8 & 12.0 & 16.2 & 16.5 & 16.0 \\
\hline Gunung Seriang & 19.5 & 16.1 & 19.2 & 14.6 & 14.6 & 19.3 & 17.7 & 17.1 & 17.6 & 17.4 & 20.0 & 14.1 & 18.4 & 18.6 & 18.1 \\
\hline Jelarai Selor & 10.3 & 6.9 & 10.0 & 5.4 & 5.4 & 10.1 & 8.5 & 7.9 & 8.4 & 8.2 & 10.8 & 5.0 & 9.2 & 9.5 & 9.0 \\
\hline Tanjung Selor Hilir & 1.9 & 6.5 & 2.1 & 6.7 & 6.7 & 1.3 & 0.4 & 0.9 & 0.4 & 0.6 & 2.8 & 6.2 & 1.0 & 1.5 & 1.5 \\
\hline Tanjung Selor Hulu & 0.9 & 8.1 & 0.6 & 8.2 & 8.2 & 1.5 & 2.0 & 2.6 & 2.1 & 2.3 & 0.8 & 7.7 & 1.3 & 0.8 & 1.6 \\
\hline Tanjung Selor Timur & 7.7 & 0.4 & 7.4 & 7.5 & 7.5 & 7.4 & 5.8 & 5.2 & 5.7 & 5.5 & 8.1 & 7.1 & 6.3 & 6.8 & 6.3 \\
\hline Tengkapak & 12.6 & 9.1 & 12.2 & 7.6 & 7.6 & 12.4 & 10.8 & 10.1 & 10.7 & 10.4 & 13.0 & 7.2 & 11.4 & 11.7 & 11.2 \\
\hline
\end{tabular}

*Food stores:

1 Agung Minimarket

2 Fardan Mart

3 King \& Queen's Market

4 Kitamart 2 Minimarket

5 Kitamart Minimarket

\author{
6 Metro Minimarket \\ 7 Mini Market Toko Tawakal \\ 8 Panen Square \\ 9 Pasar Ikan Inai-Inai \\ 10 Pasar Induk
}
11 Pasar Pagi
12 Sabanar Baru Minimarket
13 Star Swalayan
14 Toko Fajar Baru
15 Toko Riswan

Table 4. Univariate statistics of distance between population centroids to food stores.

\begin{tabular}{lrrrr}
\hline \multirow{2}{*}{$\begin{array}{c}\text { Village } \\
\text { (Population Centroid) }\end{array}$} & \multicolumn{4}{c}{ Distance to Food Store in meter } \\
\cline { 2 - 5 } & \multicolumn{1}{c}{ Minimum } & Maximum & Average & Quartile 1 \\
\hline Apung & $19,585.3$ & $25,418.7$ & $22,936.6$ & $22,043.6$ \\
Bumi Rahayu & $13,463.9$ & $19,297.3$ & $16,815.1$ & $15,922.2$ \\
Gunung Sari & $11,974.2$ & $17,807.6$ & $15,325.5$ & $14,432.5$ \\
Gunung Seriang & $14,133.8$ & $19,967.2$ & $16,873.2$ & $16,592.1$ \\
Jelarai Selor & $4,955.8$ & $10,789.3$ & $8,000.2$ & $7,414.2$ \\
Tanjung Selor Hilir & 352.3 & $6,666.0$ & $2,704.8$ & 944.7 \\
Tanjung Selor Hulu & 607.8 & $8,172.7$ & $3,238.0$ & $1,138.3$ \\
Tanjung Selor Timur & 4,175 & $8,140.4$ & $6,775.0$ & $5,764.8$ \\
Tengkapak & $7,184.2$ & $13,017.7$ & $10,056.6$ & $9,642.6$ \\
\hline
\end{tabular}

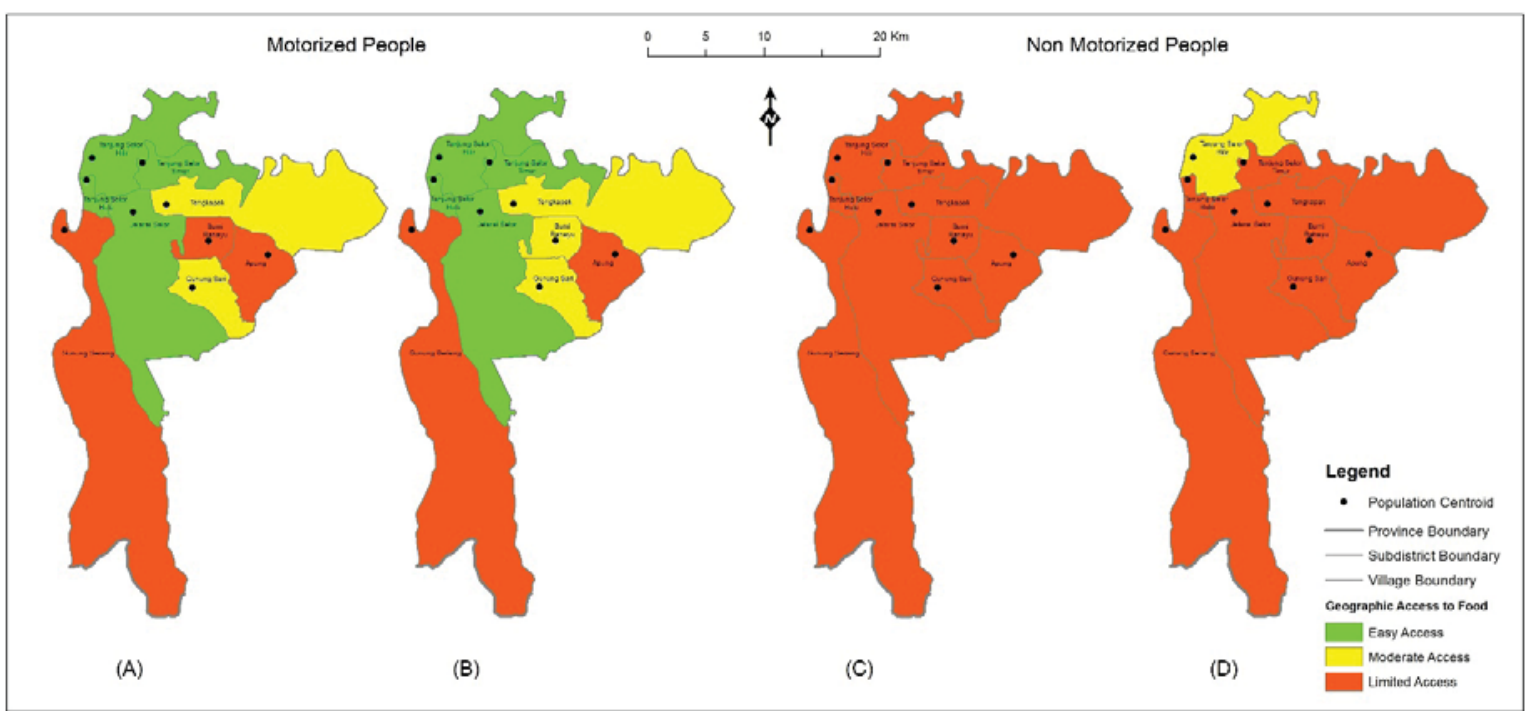

Figure 6. Visualisation of geographic access to food based on mean and first quartile distance. 


\subsection{Geographic Access to Food}

Geographical access to food in the study area is various in term of the distance separating population centre and food stores. In general, the distance range between 0.3 $\mathrm{km}$ (minimum) and $25.4 \mathrm{~km}$ (maximum) but the values are diverse among village. Table 3 provides detail information about the distance between population centers and food stores in the study area. This information was obtained from spatial network analysis which originally called origin-destination matrix (OD-matrix).

There are someimportant facts which could point out from Table 3. People live in Tanjung Selor Hilir have to travel a minimum distance of $0.3 \mathrm{~km}$ and a maximum distance of $6.6 \mathrm{~km}$ to a particular food store. In addition, they are living in the nearest distance to the main food store, i.e. Pasar Induk. This situation indicates that in general people in Tanjung Selor Hilir have easy access. Many food stores available in their neighbourhood and they are supported by adequate transportation infrastructure. On the contrary, people live in Apung Village have limited access. They have to travel a minimum distance of $19.6 \mathrm{~km}$ and a maximum distance of $22.6 \mathrm{~km}$ to a particular food store. In term of geographical access to food, Apung Village is the worst compared to others.

The different way to understand the numbers shown in Table 3 is by converting them into simpler values, i.e. minimum, maximum, average, and first quartile distance, through a univariate analysis. These values are shown in Table 4, and base on them geographical access to food were classified and spatially visualised. Figure 6 shows the visualisation of geographical access to food in the study area. This visualisation provides better insight about spatial variability of geographical access in the study area.

Figure 6 (A) and Figure 6 (B) show geographical access for motorized people, i.e. people have their own car or motorcycle. The difference between Figure 6 (A) and Figure $6(\mathrm{~B})$ is in the values used as a basis for visualisation. Figure $6(\mathrm{~A})$ is a visualisation based on average distance while Figure 6 (B) use first quartile distance as a basis. Figure 6 (C) and Figure 6 (D) shows geographical access for non-motorized people. These visualisations are based on average and first quartile distance respectively. There is a circumstance that can be revealed by the figures. Geographical access to food in the study area is limited, particularly for non-motorized people. Based on first quartile distance as a measure, only non-motorized people in Tanjung Selor Hilir has moderate access while all other villages have limited access. The situation is somewhat different for motorized people since they have better capability to reach a longer destination. In general, motorized people in the study area have moderate and easy access.

\section{Conclusion}

Tanjung Selor Subdistrict is a capital area of Bulungan Regency as well as North Kalimantan Province, the youngest province in Indonesia. Instead of a big city, like other provincial capitals in Indonesia, this area is currently a little town situated in the delta milieu. This study has revealed some fact related to geographical access to food in the study area. Food stores in the study area tend to be spatially clustered in certain location, i.e. in Tanjung Selor Hilir Village. Along with currently available roads network, this spatial distribution of food stores has affected the accessibility to food. In general, geographical access to food for non-motorized people is limited. People who do not have vehicles have to walk more than $1 \mathrm{~km}$ on average from their home to foot outlets. Access to food for motorized people is somewhat different. Motorized people live in Tanjung Selor Hilir, Tanjung Selor Timur, Tanjung Selor Hulu, and Jelarai Selor are categorized as have easy access while the people live in other villages are categorised as have moderate and limited access. This kind of information is very useful, particularly for local government to specify development priorities. Availability of public transport or vehicle ownership is necessary to improve access to food. 


\section{Acknowledgements}

The authors are grateful for financial support by Ministry of Research, Technology and Higher Education, Republic of Indonesia through "Penelitian Unggulan Perguruan Tinggi (PUPT)" grant research, and The
Institute for Research and Community Services (LPPM) Universitas Gadjah Mada. We would like to thank two anonymous reviewers for the valuable comments, correction, and suggestions

\section{References}

BPS. (2017). Kecamatan Tanjung Selor Dalam Angka 2017. Badan Pusat Statistik Kabupaten Bulungan.

Cen, X. (2017). Take the edge off: A hybrid geographic food access measure, Applied Geography, 87, 149-159.

Choi, Y., and Suzuki, T. (2013). Food deserts, activity patterns, \& social exclusion: The case of Tokyo, Japan. Applied Geography, 43, 87-98.

Eckert, J., and Shetty, S. (2011). Food systems, planning and quantifying access: Using GIS to plan for food retail. Applied Geography, 31, 1216-1223.

Fotheringham, A.S. and Rogerson, P.A. (Eds) (2009). The SAGE Handbook of Spatial Analysis. SAGE Publications Ltd, London.

FAO. (2013). Food Security Statistics, FAO Statistics Division. Food and Agriculture Organization of the United Nations, Rome, Italy.

Goodchild, M. F. (2007).Citizens as sensors: The world of volunteered geography. GeoJournal, 69(4), 211-221.

Harini, R., Handayani, H.N., and Ramdani, F.R. (2018). Food security assessment in the coastal area of Demak Regency. IOP Conf. Series: Earth and Environmental Science 148:012015. doi :10.1088/1755-1315/148/1/012015.

Jestico, B., Nelson, T. and Winters, M. (2016). Mapping ridership using crowdsourced cycling data. Journal of Transport Geography, 52, 90-97.

Johnson, B.A., Iizuka, K., Bragais, M.A., Endo, I. and Macandog, D.B.M. (2017). Employing crowdsourced geographic data and multi-temporal/multi-sensor satellite imagery to monitor land cover change: A case study in an urbanizing region of the Philippines. Computers, Environment and Urban Systems,64, 184-193.

Krizan, F., Bilkova, K., Kita, P., and Hornak, M. (2015). Potential food deserts and food oases in a post-communist city: Access, quality, variability and price of food in Bratislava-Petrzalka. Applied Geography, 62, 8-18.

Le, Q., Nguyen, H.B., Terry, D.R., Dieters, S., Auckland. S. and Long, G. (2015). Quantifying and visualizing access to healthy food in a rural area of Australia: A spatial analysis, Food Security, 7,1017-1029.

Leroy, J.L., Ruel, M., Frongillo, E.A., Harris, J., and Ballard, T.J. (2015). Measuring the Food Access Dimension of Food Security: A Critical Review and Mapping of Indicators, Food and Nutrition Bulletin, 36(2), 167-195.

Susilo, B. (2016). Map Analysis and Spatial Statistic: Assessment of Spatial Variability of Agriculture Land Conversion at Urban Fringe Area of Yogyakarta. IOP Conf. Series: Earth and Environmental Science 47:012001. doi:10.1088/1755-1315/47/1/012001.

Widiyanto, D. (2018) .An Exploration of Food Insecurity, Poverty, Livelihood and Local Food Potentials in Kulon Progo Regency, Indonesia. Forum Geografi, 32(1), 64-87.

Yeager, C.D. and Gatrell, J.D. (2014). Rural food accessibility: An analysis of travel impedance and the risk of potential grocery closures. Applied Geography, 53, 1-10. 